\title{
Giant otter (Pteronura brasiliensis): a database of specimens held in major Brazilian zoological collections.
}

\begin{abstract}
Salvatore Siciliano ${ }^{* 1}$, Gisele M. L. Giudice ${ }^{2}$, Renato N. Feio ${ }^{2}$, Renata Emin-Lima ${ }^{3}$, Alexandra F. Costa ${ }^{4}$, Fabio 0. Nascimento ${ }^{5}$, Fabiano R. Melo ${ }^{6}$, Guilherme S. T. Garbino ${ }^{2}$
\end{abstract}

\begin{abstract}
This dataset compiles information on giant otter (Pteronura brasiliensis) specimens housed in the major zoological collections of Brazil. We have personally examined the specimens, which constitute of skins, crania, and partial skeletons. We compiled information on collector, date, and locality of the specimens. A total of 56 giant otter specimens housed in six zoological collections were located. Of this total, 12 specimens do not have associated locality information. Of special relevance are the specimens from the Brazilian state of Rio Grande do Sul, Minas Gerais, and São Paulo, as they document the presence of the giant otter in the Atlantic rainforest, where it is now extirpated. Our dataset may be used in studies on distribution (past and present) of the species, and to delineate conservation policies of the giant otter. The specimens from the Atlantic rainforest may be used in museomics analyses, as they may represent lost haplotypes of $P$. brasiliensis.
\end{abstract}

Keywords: Mammalia; Carnivora; Mustelidae; Lutrinae; Collection.

\section{PRIOR PUBLICATIONS}

BRANDÃO, M.V., et al. Mammals of Mato Grosso, Brazil: Annotated species list and historical review. Mastozoología Neotrop. 26(2):1-44. 2019. DOI: https://dx.doi.org/10.31687/saremMN.19.26.2.0.03.

CÁCERES, N. C. et al. Mammals from Mato Grosso do Sul, Brazil. Check List, v. 4, n. 3, p. 321-335, 2008. Available at: <https://www.biotaxa.org/cl/article/view/4.3.321>. Date accessed: 28 Apr. 2021. DOI: http://dx.doi.org/10.15560/4.3.321

DE VIVO, M., et al. Checklist of mammals from São Paulo State, Brazil. Biota Neotrop. 11(1a): http://www.biotaneotropica.org.br/v11n1a/en/abstract?i nventory+bn0071101a2011.

NASCIMENTO, F. O.; VENDRAMEL, R. L. Catalog of medium and large-sized mammals from the state of Pará, Brazil, housed in the Museu de Zoologia da Universidade de São Paulo (MZUSP). Boletim do Museu

\footnotetext{
${ }^{1}$ Grupo de Estudos de Mamíferos Marinhos da Região dos Lagos (GEMM-Lagos), Fundação Oswaldo Cruz, Rio de Janeiro, RJ, Brasil. gemmlagos@gmail.com.

${ }^{2}$ Museu de Zoologia João Moojen, Universidade Federal de Viçosa (UFV), Viçosa, MG, Brasil.

${ }^{3}$ Museu Paraense Emílio Goeldi (MPEG), Belém, PA, Brasil.

${ }^{4}$ Instituto Bicho D'água: Conservação Socioambiental, Belém, PA, Brasil.

${ }^{5}$ Museu de Zoologia da Universidade de São Paulo (MZUSP), São Paulo, SP, Brasil.

${ }^{6}$ Departamento de Engenharia Florestal, Universidade Federal de Viçosa (UFV), Viçosa, MG, Brasil.
} 
Paraense Emílio Goeldi. Ciências Naturais 15(3): 863-903. $2020 . \quad$ DOI: http://doi.org/10.46357/bcnaturais.v15i3.240

SICILIANO, S.; FRANCO, S. M. S. Catálogo da Coleção de Mamíferos Aquáticos do Museu Nacional. Rio de Janeiro: FIOCRUZ, 2005.

SICILIANO, S. et al. Revisão do conhecimento sobre os mamíferos aquáticos da Costa Norte do Brasil. Arquivos do Museu Nacional, v. 66, n. 2, p. 381-401, 2008.

TOMAS, W. M. et al. Checklist of mammals from Mato Grosso do Sul, Brazil. Iheringia, Sér. Zool., Porto Alegre, v. 107, supl. e2017155, 2017. https://doi.org/10.1590/1678-4766e2017155.

VIEIRA, C.O.C. Carnívoros do Estado de São Paulo. Arq. Zool. 5(3): 135-176. 1946.

\section{DATA IMPORTANCE}

- The intense selective hunting of mammals for the fur trade throughout the 20th century in Brazilian Amazonia has caused a dramatic population decline of giant otters (Pteronura brasiliensis) (ANTUNES et al., 2014).

- Museum records provide the only reliable evidence of past occurrence of giant otters in the Brazilian Atlantic Rainforest and associated habitats in the states of Minas Gerais (MZUFV 17; Fig. 1), São Paulo (MZUSP 2323, MZUSP 4063) and Rio Grande do Sul (MZUSP 1658; Fig. 2).

- Museum specimens are the main source of historical data for giant otters at its present eastern limit of distribution in Brazil, i.e., the Araguaia River, Cantão State Park, Tocantins;

- On the other hand, museum records can indicate the location of remnant populations of giant otters' records, some in possible expansion, like the Brazilian Pantanal;

- Specimens representing populations that are now extirpated may also be used in museomics analyses, allowing for the assessment of the haplotypic variety of these populations.

Figure 1. Mounted specimen of Pteronura brasiliensis, juvenile specimen (MZUFV 017), collected by João Moojen de Oliveira in Minas Gerais (near Rio Doce river), Brazil. A) Detail of the dorsoventrally flattened tail, B) detail of the anterior region.

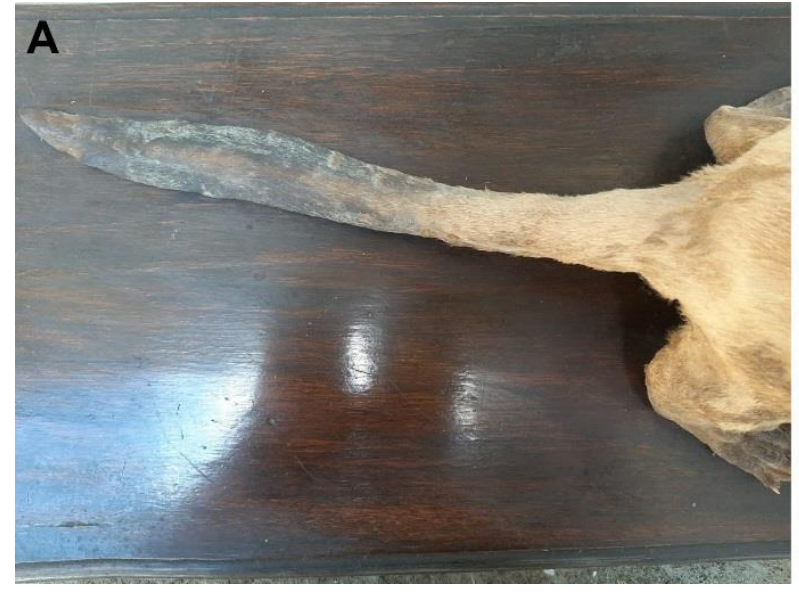

\section{MATERIALS AND METHODS}

The major mammal collections of museums and universities in Brazil were visited in search of giant otter (Pteronura brasiliensis) records. These

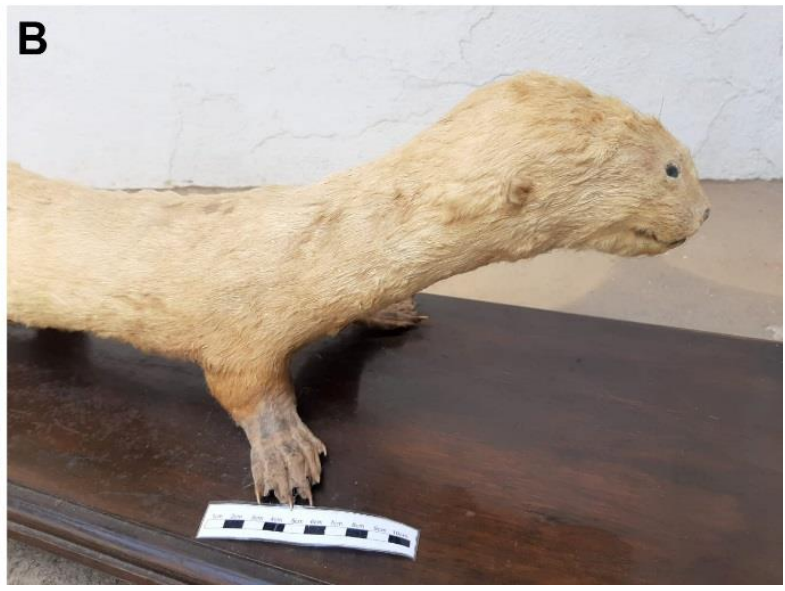

collections are: Museu Paraense Emílio Goeldi (MPEG), Universidade Federal de Mato Grosso (UFMT), Pontifícia Universidade Católica de Minas Gerais (PUC-MG), Museu Nacional/UFRJ (MN), Museu de Zoologia da Universidade Federal de 
Viçosa (MZUFV), Universidade Federal de Minas Gerais (UFMG), Museu de Zoologia da USP (MZUSP) and Museu de Zoologia da Universidade Estadual de Campinas (ZUEC-MAM). Specimens were cross-checked with the available literature, to provide a complete list of specimens and associated data.

\section{DATA DESCRIPTION}

In total there are 56 specimens deposited, collected from 1903 to 2005. Locality information could be obtained for most ( 45 out of 56 ) of the specimens. A total of 13 specimens do not have precise localities and are either represented by captive animals (with no information on place of origin) or were obtained from skin trading posts.

Major biomes in Brazil are represented, except the Caatinga. Most specimens (56\%) were collected in the Amazon Rainforest. There is a single record from the Pampas (São Lourenço do Sul; collected in 1904; Fig. 2), a transition area between this domain and the Atlantic Rainforest.

Most interesting are the specimens from São Paulo, Minas Gerais and Rio Grande do Sul, where $P$. brasiliensis is now considered extinct. This is of great strategic importance to guide evaluation of current giant otter presence and their threats.

Figure 2. Skull of giant otter, Pteronura brasiliensis (MZUSP 1658), from São Lourenço do Sul, Rio Grande do Sul state, Brazil.

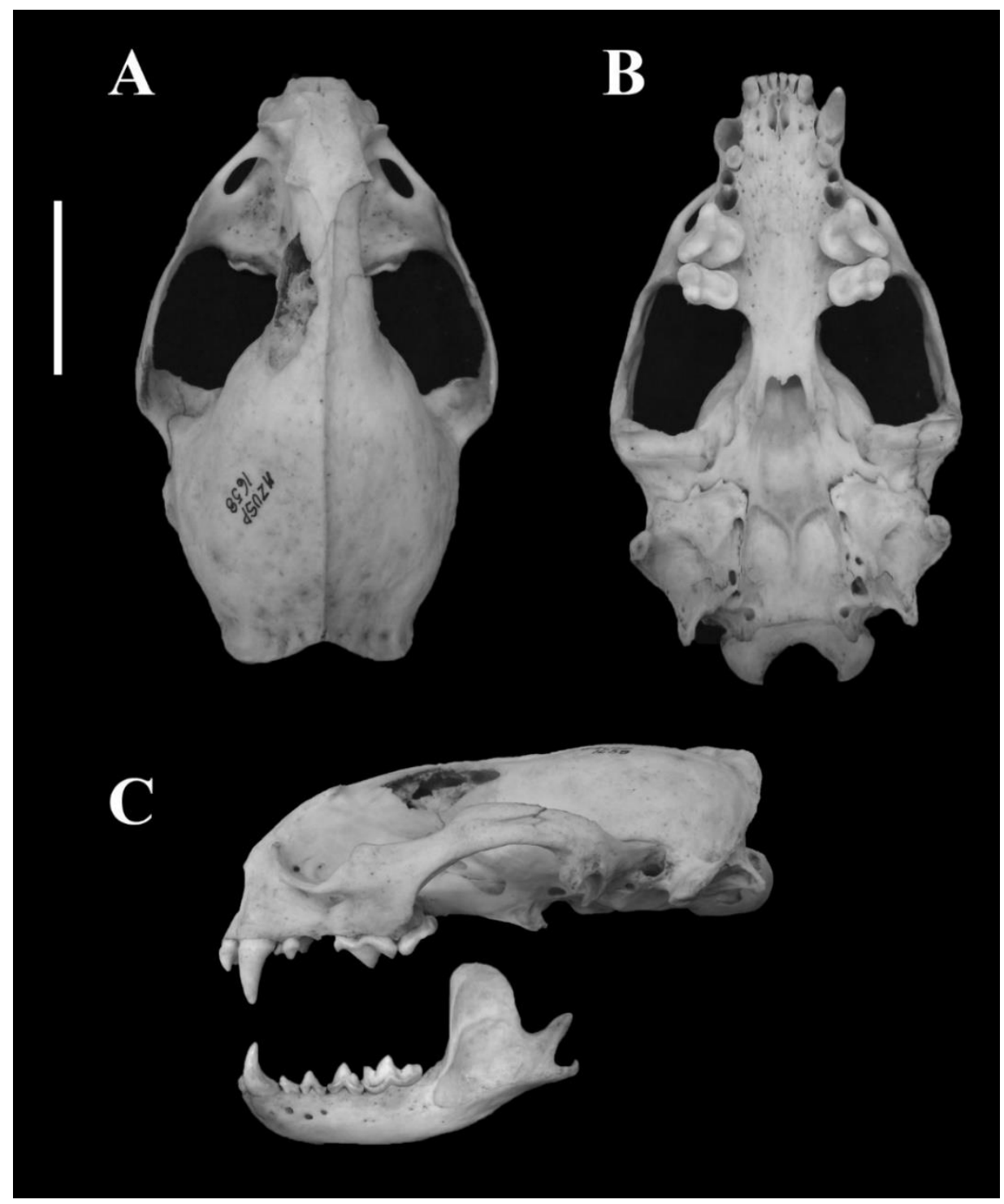




\section{Dataset}

The dataset was formatted using excel .csv, a plain text format, in which values are separated by commas (Comma Separated Values). Our dataset ("Pteronura_brazil.csv") lists the available specimens deposited in the major zoological collections in Brazil, including data on voucher specimens, locality, date of collection, gender, material deposited and primary reference. The column "Voucher specimen" refers to a preserved animal specimen, all or a portion (skin, skull, tissues) that is collected, preserved, and maintained as reference material in a museum as a permanent reference; "State" refers to a federated state within a territorial and constitutional community forming part of the Brazilian federation; "Locality" refers to a place, spot, or district, where the collection of the organism was made; "Date of collection" refers to the day, month and year of the collection of the referred specimen; "Gender" is either the male or female division of a species; "Material deposited" refers to the piece of evidence that was examined and checked for future reference; "Primary reference" refers to the very first scientific peerreviewed publication that lists the referred voucher specimen(s), they are: Brandão et al. (2019), Cáceres et al. (2008), De Vivo et al. (2011), Nascimento and Vendramel (2020), Siciliano et al. (2008), Tomas et al. (2017) and Vieira (1946).

\title{
SUPPLEMENTARY MATERIALS
}

\author{
Dataset: Pteronura_brazil.csv
}

\section{ACKNOWLEDGEMENTS}

We are grateful to the curators and managers of the visited collections, for allowing us to examine the specimens under their care. S.S. acknowledges CNPq for the scholarship (Produtividade em Pesquisa).

\section{REFERENCES}

BRANDÃO, M. V., et al. Mammals of Mato Grosso, Brazil: Annotated species list and historical review. Mastozoología Neotrop. 26(2):1-44. 2019.

CÁCERES, N. C. et al. Mammals from Mato Grosso do Sul, Brazil. Check List, v. 4, n. 3, p. 321-335, 2008. Available at: <https://www.biotaxa.org/cl/article/view/4.3.321>. Date accessed: 28 Apr. 2021. doi: http://dx.doi.org/10.15560/4.3.321

DE VIVO, M., et al. Checklist of mammals from São Paulo State, Brazil. Biota Neotrop. 11(1a): http://www.biotaneotropica.org.br/v11n1a/en/abstract?i nventory+bn0071101a2011.

NASCIMENTO, F. O.; VENDRAMEL, R. L. Catalog of medium and large-sized mammals from the state of Pará, Brazil, housed in the Museu de Zoologia da Universidade de São Paulo (MZUSP). Boletim do Museu Paraense Emílio Goeldi. Ciências Naturais 15(3): 863-903. 2020. DOI: http://doi.org/10.46357/bcnaturais.v15i3.240

SICILIANO, S. et al. Revisão do conhecimento sobre os mamíferos aquáticos da Costa Norte do Brasil. Arquivos do Museu Nacional, v. 66, n. 2, p. 381-401, 2008.

TOMAS, W. M. et al. Checklist of mammals from Mato Grosso do Sul, Brazil. Iheringia, Sér. Zool., Porto Alegre, v. 107, supl. e2017155, 2017. DOI: https://doi.org/10.1590/1678-4766e2017155.

VIEIRA, C. O. C. Carnívoros do Estado de São Paulo. Arq. Zool. 5(3): 135-176, 1946. 